\title{
Determinants of condom breakage among female sex workers in Karnataka, India
}

Janet Bradley ${ }^{1,2^{*}}$, S Rajaram ${ }^{1,3}$, Michel Alary ${ }^{1,2}$, Shajy Isac $^{3}$, Reynold Washington ${ }^{3,4}$, Stephen Moses ${ }^{3,4}$, BM Ramesh ${ }^{3,4}$

\begin{abstract}
Background: Condoms are effective in preventing the transmission of HIV and other sexually transmitted infections, when properly used. However, recent data from surveys of female sex workers (FSWs) in Karnataka in south India, suggest that condom breakage rates may be quite high. It is important therefore to quantify condom breakage rates, and examine what factors might precipitate condom breakage, so that programmers can identify those at risk, and develop appropriate interventions.

Methods: We explored determinants of reported condom breakage in the previous month among 1,928 female sex workers in four districts of Karnataka using data from cross-sectional surveys undertaken from July 2008 to February 2009. Using stepwise multivariate logistic regression, we examined the possible determinants of condom breakage, controlling for several independent variables including the district and client load.

Results: Overall, $11.4 \%$ of FSWs reported at least one condom break in the previous month. FSWs were much more likely to report breakage if under 20 years of age (AOR 3.43, $p=0.005$ ); if divorced/ separated/widowed (AOR $1.52, p=0.012$ ); if they were regular alcohol users (AOR 1.63, $p=0.005$ ); if they mostly entertained clients in lodges/rented rooms (AOR 2.99, $p=0.029$ ) or brothels ( $A O R$ 4.77, $p=0.003$ ), compared to street based sex workers; if they had ever had anal sex (AOR 2.03, $p=0.006$ ); if the sex worker herself (as opposed to the client) applied the condom at last use (AOR 1.90, $p<0.001$ ); if they were inconsistent condom users (AOR 2.77, $p<$ 0.001); and if they had never seen a condom demonstration (AOR 2.37, $p<0.001$ ).

Conclusions: The reported incidence of condom breakage was high in this study, and this is a major concern for HIV/STI prevention programs, for which condom use is a key prevention tool. Younger and more marginalized female sex workers were most vulnerable to condom breakage. Special effort is therefore required to seek out such women and to provide information and skills on correct condom use. More research is also needed on what specific situational parameters might be important in predisposing women to condom breakage.
\end{abstract}

\section{Introduction}

Condom use is a key strategy for preventing sexually transmitted infections, including HIV [1,2]. However, condoms are only effective in preventing infection if they do not break or slip off during intercourse, and if they are correctly applied before initial penetration [3-7]. Published data show that condoms break approximately $1-13 \%$ of the time, depending on the population [8]. Data from Africa and India generally show much higher rates of breakage. In a study of female sex

\footnotetext{
* Correspondence: jbradley@uresp.ulaval.ca

${ }^{1}$ CHARME-India Project, Bangalore; India KHPT office, IT Park $5^{\text {th }}$ floor, \#1-4 Rajajinagar Industrial Area, Behind KSSIDC Admin Office, Rajajinagar, Bangalore 560 044, India

Full list of author information is available at the end of the article
}

workers (FSWs) in Benin in 2005, Mukenge-Tshibaka et al. [9] reported that $33 \%$ had experienced a breakage in the previous 2 days. Data from female sex workers in four southern states of India are available from face-toface interviews (FTFI) in cross-sectional studies termed integrated biological and behavioural assessments (IBBAs). The percentage of FSWs reporting condom breakage at least once in the last month ranged from $5 \%$ in Thane, Maharashtra $(\mathrm{MH})$ to $55 \%$ in Vizag, Andhra Pradesh (AP), with rates generally very high in districts in AP (ranging from $29 \%$ to $55 \%$ ), and low in districts in Tamil Nadu (ranging from $2 \%$ in Chennai to $14 \%$ in Dharmapuri) [10].

The objective of this exploratory study was to compare, in a large sample of female sex workers in four

\section{Biomed Central}


districts of Karnataka south India, the personal characteristics of those who reported a condom breakage in the previous month with those who did not. We examined aspects such as socio-demographic background, usual place of solicitation and place of sex, other aspects of sex work (e.g. practice of anal sex), client load, condom use, HIV knowledge, other risk factors such as alcohol use and history of violence, and exposure to programmatic interventions. The findings are important for determining if some women are more susceptible to breakage than others and thus for developing targeted programme interventions for those most at risk.

\section{Methods}

As part of the evaluation of the Indian Avahan AIDS intervention, two rounds of IBBAs were undertaken in several urban areas of four south India districts of Karnataka (Belgaum, Bellary, Bangalore and Shimoga), with the Round 2 surveys, that we focus on here, done between July 2008 and February 2009 [11]. The studies included a face-to-face interview and taking of blood samples for STI and HIV testing with a total of 1,975 female sex workers, of whom 1,928 reported they had used condoms in the last month. One of the questions asked in the survey was whether the respondent experienced a condom breakage during use in the previous month. The respondents were selected randomly using time-location cluster sampling, based on a previously developed map of urban sex work sites that served as a sampling framework [11]. The data were merged and appropriate weights added to account for a complex sampling design. After univariate analysis, some variables, where the odds ratios were similar for different categories, were re-categorized for simplicity, and we included in the first model, only those variables that were significantly associated with breakage in univariate analysis $(\mathrm{p}<0.05)$. We used stepwise logistic regression in a series of model iterations to determine the factors most associated with condom breakage, controlling also for both district and client load.

\section{Results}

Of 1,928 FSWs interviewed, 220 (11.4\%) reported that they had experienced a breakage in the month prior to the survey. On univariate analysis, compared to the entire sample, $17.1 \%$ of those who were found to be HIV positive reported a break (OR 1.78, $p=0.008$ ), as did $20.7 \%$ of those with chlamydial infection (OR 2.17, $p=0.001$ ), and $30.0 \%$ of those with gonorrhoea (OR 3.54, $p=0.001)$. Twenty-two percent of the women who reported a breakage were in fact HIV positive, compared to $14 \%$ of those who did not report a breakage.

Table 1 shows factors in univariate analysis associated with condom breakage; some factors were not associated with breakage and so are not included in Table 1 (literacy, being in debt, age at first sex, how much the last client paid for sex, heard of STIs, heard of HIV, felt at risk of HIV, ever taken an HIV test). Breakage was least likely to be reported in Shimoga (6.1\%) and most likely in urban Bangalore (16.7\%). Women with more clients were, as expected, more likely to have had a breakage in the previous month, with those having more than twenty per week almost twice as likely to report breakage than those only having 1-4 clients. Some demographic factors and sex work practices appeared to be associated with reporting of breakages. Young women under the age of 20 years were much more likely to report breakage than older women, as were women who were divorced, separated or widowed, those new to sex work, and those who had also practiced sex work in other towns. Women who reported that they had ever had anal sex and those who reported violence, or had been arrested, were twice as likely to say that they had experienced a condom break. Those women who entertained their clients at home reported breakage less than those working elsewhere; women working in brothels reported breakage four times more than women entertaining at home. Alcohol use appeared to be an important factor; women who said they drink alcohol were 23 times more likely to report a condom break in the month before the survey.

Aspects of condom use were also important. Those women who received their last condom from a peer educator (i.e. a government condom) were much less likely to report a condom break than those who received them elsewhere. Consistency of condom use was important: those who had not used condoms every time in the previous month were three times more likely to report that one had broken. Interestingly, women who said they themselves had been the ones to apply the last male condom they had used were more than twice as likely to report a breakage as when the client applied the condom. Programme exposure variables were also included in the analysis. Respondents who said that they were registered with a sex worker community-based organization $(\mathrm{CBO})$, were two and a half times less likely to report breakage than those women who were not part of a CBO. Similarly if they had ever received condoms from a peer educator and if they had seen a condom demonstration, they were two to three times less likely to report breakage than those without this type of exposure.

In the logistic regression model (Table 2), we found that respondents under 20 years of age were more than three times more likely than women aged 20 or older to have reported a condom breakage in the previous month (AOR 3.42, 95\% CI 1.89-6.23, p<0.001); divorced, separated or widowed women more likely to report 
Table 1 Univariate analysis of factors associated with condom breakage

\begin{tabular}{|c|c|c|c|c|c|}
\hline Factor & Response categories & $\begin{array}{l}\% \text { broke in last } \\
\text { month }\end{array}$ & $\begin{array}{l}\text { Odds } \\
\text { ratio }\end{array}$ & $\begin{array}{l}95 \% \text { confidence } \\
\text { intervals }\end{array}$ & $\begin{array}{l}p \\
\text { value }\end{array}$ \\
\hline District & $\begin{array}{l}\text { Shimoga } \\
\text { Belgaum } \\
\text { Bellary } \\
\text { Bangalore }\end{array}$ & $\begin{array}{l}6.09 \\
12.65 \\
9.15 \\
16.70\end{array}$ & $\begin{array}{l}\text { Ref } \\
2.23 \\
1.55 \\
3.09\end{array}$ & $\begin{array}{l}1.28-3.90 \\
0.81-2.99 \\
1.78-5.36\end{array}$ & $\begin{array}{l}0.005 \\
0.188 \\
<0.001\end{array}$ \\
\hline Number of clients in typical week & $\begin{array}{l}1-4 \\
5-9 \\
10-19 \\
20+\end{array}$ & $\begin{array}{l}9.59 \\
8.73 \\
10.99 \\
16.30\end{array}$ & $\begin{array}{l}\text { Ref } \\
0.90 \\
1.16 \\
1.83\end{array}$ & $\begin{array}{l}0.55-1.49 \\
0.75-1.80 \\
1.13-2.97\end{array}$ & $\begin{array}{l}0.684 \\
0.497 \\
0.014\end{array}$ \\
\hline \multicolumn{6}{|l|}{ Demographic factors } \\
\hline Age & $\begin{array}{l}40+ \\
35-39 \\
30-34 \\
20-24 \\
<20\end{array}$ & $\begin{array}{l}9.12 \\
10.17 \\
13.00 \\
12.78 \\
30.56\end{array}$ & $\begin{array}{l}\text { Ref } \\
1.12 \\
1.49 \\
1.46 \\
4.39 \\
\end{array}$ & $\begin{array}{l}0.71-1.79 \\
0.96-2.31 \\
0.91-2.35 \\
2.44-7.89\end{array}$ & $\begin{array}{l}0.608 \\
0.075 \\
0.116 \\
0.000\end{array}$ \\
\hline Marital status & $\begin{array}{l}\text { Devadasi (traditional FSW) } \\
\text { Divorced/separated/ } \\
\text { widowed } \\
\text { Never married } \\
\text { Married }\end{array}$ & $\begin{array}{l}4.84 \\
13.58 \\
12.03 \\
10.57\end{array}$ & $\begin{array}{l}\text { Ref } \\
3.09 \\
2.69 \\
2.32\end{array}$ & $\begin{array}{l}1.36-7.03 \\
1.07-6.73 \\
1.04-5.21\end{array}$ & $\begin{array}{l}0.007 \\
0.035 \\
0.041\end{array}$ \\
\hline \multicolumn{6}{|l|}{ Sex work and personal risk factors } \\
\hline Duration of sex work in this district & $\begin{array}{l}>5 \text { years } \\
1-4 \text { years } \\
<1 \text { year }\end{array}$ & $\begin{array}{l}10.20 \\
11.29 \\
18.23\end{array}$ & $\begin{array}{l}\text { Ref } \\
1.12 \\
1.96\end{array}$ & $\begin{array}{l}0.78-1.61 \\
1.09-3.53\end{array}$ & $\begin{array}{l}0.538 \\
0.024\end{array}$ \\
\hline Ever practiced sex in a different place & $\begin{array}{l}\text { No } \\
\text { Yes }\end{array}$ & $\begin{array}{l}10.16 \\
20.93\end{array}$ & $\begin{array}{l}\text { Ref } \\
2.34\end{array}$ & $1.54-3.55$ & $<0.001$ \\
\hline Ever had anal sex & $\begin{array}{l}\text { No } \\
\text { Yes }\end{array}$ & $\begin{array}{l}10.17 \\
19.80\end{array}$ & $\begin{array}{l}\operatorname{Ref} \\
2.18\end{array}$ & $1.39-3.42$ & 0.001 \\
\hline Been forced to have sex in the last year & $\begin{array}{l}\text { No } \\
\text { Yes }\end{array}$ & $\begin{array}{l}10.53 \\
20.08\end{array}$ & $\begin{array}{l}\operatorname{Ref} \\
2.13\end{array}$ & $1.37-3.32$ & 0.001 \\
\hline Ever been arrested & $\begin{array}{l}\text { No } \\
\text { Yes }\end{array}$ & $\begin{array}{l}10.15 \\
21.50\end{array}$ & $\begin{array}{l}\text { Ref } \\
2.42\end{array}$ & $1.54-3.81$ & $<0.001$ \\
\hline Main place of entertaining clients & $\begin{array}{l}\text { Public places } \\
\text { Home } \\
\text { Rented room/lodge } \\
\text { Brothels }\end{array}$ & $\begin{array}{l}6.42 \\
7.54 \\
13.80 \\
21.95\end{array}$ & $\begin{array}{l}\text { Ref } \\
1.19 \\
2.32 \\
4.10\end{array}$ & $\begin{array}{l}0.51-2.77 \\
1.02-5.32 \\
1.67-10.08\end{array}$ & $\begin{array}{l}0.686 \\
0.046 \\
0.002\end{array}$ \\
\hline Drink alcohol & $\begin{array}{l}\text { Never } \\
\text { Occasionally } \\
\text { Regularly }\end{array}$ & $\begin{array}{c}8.27 \\
21.00 \\
17.03 \\
\end{array}$ & $\begin{array}{l}\text { Ref } \\
2.95 \\
2.28 \\
\end{array}$ & $\begin{array}{l}1.71-5.09 \\
1.63-3.17\end{array}$ & $\begin{array}{l}<0.001 \\
<0.001\end{array}$ \\
\hline \multicolumn{6}{|l|}{ Condom use } \\
\hline $\begin{array}{l}\text { Always used condoms in the last } 30 \\
\text { days }\end{array}$ & $\begin{array}{l}\text { Yes } \\
\text { No }\end{array}$ & $\begin{array}{r}9.08 \\
23.77\end{array}$ & $\begin{array}{l}\text { Ref } \\
3.12\end{array}$ & $2.24-4.36$ & 0.001 \\
\hline Where last condom was obtained & $\begin{array}{l}\text { Peer educator/health facility } \\
\text { Client } \\
\text { Other }\end{array}$ & $\begin{array}{l}10.36 \\
16.17 \\
20.93 \\
\end{array}$ & $\begin{array}{l}\text { Ref } \\
1.66 \\
2.29 \\
\end{array}$ & $\begin{array}{l}1.08-2.57 \\
1.42-3.69\end{array}$ & $\begin{array}{l}0.020 \\
0.001\end{array}$ \\
\hline Last time condom was put on by? & $\begin{array}{l}\text { Client } \\
\text { Respondent }\end{array}$ & $\begin{array}{l}7.65 \\
16.30\end{array}$ & $\begin{array}{l}\operatorname{Ref} \\
2.35\end{array}$ & $1.70-3.26$ & $<0.001$ \\
\hline \multicolumn{6}{|l|}{ Programme exposure } \\
\hline Registered with sex worker CBO & $\begin{array}{l}\text { Yes } \\
\text { No }\end{array}$ & $\begin{array}{l}10.17 \\
21.65\end{array}$ & $\begin{array}{l}\operatorname{Ref} \\
2.44\end{array}$ & $1.66-3.59$ & $<0.001$ \\
\hline Ever given condom by a peer educator & $\begin{array}{l}\text { Yes } \\
\text { No }\end{array}$ & $\begin{array}{l}10.28 \\
21.43\end{array}$ & $\begin{array}{l}\text { Ref } \\
2.38\end{array}$ & $1.62-3.50$ & $<0.001$ \\
\hline Ever seen a condom demonstration & $\begin{array}{l}\text { Yes } \\
\text { No }\end{array}$ & $\begin{array}{l}10.14 \\
23.91\end{array}$ & $\begin{array}{l}\text { Ref } \\
2.79\end{array}$ & $1.94-4.00$ & $<0.001$ \\
\hline
\end{tabular}


Table 2 Logistic regression analysis of factors associated with condom breakage

\begin{tabular}{|c|c|c|c|c|}
\hline Factor & Response categories & $\begin{array}{l}\text { Adjusted odds } \\
\text { ratio }\end{array}$ & $\begin{array}{l}95 \% \text { confidence } \\
\text { intervals }\end{array}$ & $\begin{array}{l}p \\
\text { value } \\
\end{array}$ \\
\hline District & $\begin{array}{l}\text { Shimoga } \\
\text { Belgaum } \\
\text { Bellary } \\
\text { Bangalore }\end{array}$ & $\begin{array}{l}\text { Ref } \\
1.47 \\
1.20 \\
2.26 \\
\end{array}$ & $\begin{array}{l}0.80-2.71 \\
0.65-2.24 \\
1.30-3.91\end{array}$ & $\begin{array}{c}0.213 \\
0.55 \\
10.004\end{array}$ \\
\hline Number of clients in typical week & $\begin{array}{l}1-4 \\
5-9 \\
10-19 \\
20+ \\
\end{array}$ & $\begin{array}{l}\text { Ref } \\
0.84 \\
1.18 \\
1.37 \\
\end{array}$ & $\begin{array}{l}0.50-1.41 \\
0.70-1.97 \\
0.77-2.43\end{array}$ & $\begin{array}{l}0.50 \\
40.54 \\
10.273\end{array}$ \\
\hline \multicolumn{5}{|l|}{ Demographic factors } \\
\hline Age & $\begin{array}{l}20 \text { and above } \\
<20\end{array}$ & $\begin{array}{l}\text { Ref } \\
3.43\end{array}$ & $1.89-6.23$ & $<0.001$ \\
\hline Marital status & $\begin{array}{l}\text { Never married/married/devadasi Divorced/separated/ } \\
\text { widowed }\end{array}$ & $\begin{array}{l}\text { Ref } \\
1.52\end{array}$ & $1.10-2.10$ & 0.012 \\
\hline \multicolumn{5}{|l|}{ Sex work and personal risk factors } \\
\hline Ever had anal sex & $\begin{array}{l}\text { No } \\
\text { Yes }\end{array}$ & $\begin{array}{l}\operatorname{Ref} \\
2.03\end{array}$ & $1.23-3.36$ & 0.006 \\
\hline Main place of entertaining clients & $\begin{array}{l}\text { Public places } \\
\text { Home } \\
\text { Rented room/lodge } \\
\text { Brothels }\end{array}$ & $\begin{array}{r}\text { Ref } \\
1.9 \\
2.99 \\
4.78\end{array}$ & $\begin{array}{l}1.35-2.68 \\
1.12-8.01 \\
1.69-13.48\end{array}$ & $\begin{array}{l}0.196 \\
0.029 \\
0.003\end{array}$ \\
\hline Drink alcohol & $\begin{array}{l}\text { Never } \\
\text { Ever }\end{array}$ & $\begin{array}{l}\text { Ref } \\
1.63\end{array}$ & $1.16-2.28$ & 0.005 \\
\hline \multicolumn{5}{|l|}{ Condom use } \\
\hline $\begin{array}{l}\text { Always used condoms in the last } 30 \\
\text { days }\end{array}$ & $\begin{array}{l}\text { Yes } \\
\text { No }\end{array}$ & $\begin{array}{l}\text { Ref } \\
2.77\end{array}$ & $1.87-4.11$ & $<0.001$ \\
\hline Last time condom was put on by? & $\begin{array}{l}\text { Client } \\
\text { Respondent }\end{array}$ & $\begin{array}{l}\operatorname{Ref} \\
1.90\end{array}$ & $1.35-2.68$ & $<0.001$ \\
\hline \multicolumn{5}{|l|}{ Programme exposure } \\
\hline Ever seen a condom demonstration & $\begin{array}{l}\text { Yes } \\
\text { No }\end{array}$ & $\begin{array}{l}\text { Ref } \\
2.37\end{array}$ & $1.65-3.40$ & $<0.001$ \\
\hline
\end{tabular}

breakage than unmarried or currently married women (AOR 1.52, 95\% CI 1.10-2.10, $\mathrm{p}=0.012$ ); users of alcohol had a higher risk if reporting breakage (AOR 1.61, 95\% CI 1.16-2.28 $\mathrm{p}=0.005)$; those who primarily entertained clients in lodges/rented rooms (AOR 2.99, 95\% CI 1.128.01. $\mathrm{p}=0.029$ ) or brothels (AOR 4.78, 95\% CI 1.69$13.48, \mathrm{p}=0.003$ ) were more likely to report breakage rather than those who primarily entertained their clients in public places. Those women who reported that they had ever had anal sex were twice more likely than others to report breakage (AOR 2.03, 95\% CI 1.23-3.36, $\mathrm{p}=0.006$ ). Those sex workers who reported that they had been the one to put the condom during the last time one was used were more likely to report breakage (AOR 1.90, 95\% CI 1.35-2.68, $\mathrm{p}=<0.001$ ) and if the sex workers reported inconsistent (less than 100\%) condom use in the last month, they were almost three times more likely to report breakage than consistent condom users (AOR 2.77, 95\% CI 1.87-4.11, p<0.001). Those who had never seen a condom demonstration were more than twice more likely to report breakage in the last month than those who had seen a demonstration
(AOR 2.37, 95\% CI 1.65-3.40, $\mathrm{p}<0.001$ ). Other variables associated with sex practices and with other aspects of programme exposure were not associated with breakage in the multivariate regression model.

\section{Conclusions and discussion}

There have been many studies that have examined factors associated with condom breakage, though they often only evaluate aspects of the sex act where a break occurred, rather than looking at over-arching population variables. Furthermore, most studies have been done in developed countries and in non-commercial sex settings, and with a limited number of subjects. A limitation of this study is that the IBBA data do not give us specific details of the sex act in which the condom breaks, and we can only examine personal factors. A further limitation of this study is that we asked only about whether condom breakage had occurred in the past month, not the number of times that breakage occurred as a proportion of all sex acts (i.e. the frequency of condom breakage). More research is needed on the frequency of breakage to better assess the potential impact of 
condom breakage on the HIV epidemic among FSWs in the context of high condom use levels. However, this study is a useful complement to the literature because it examines, in a large sample of female sex workers with many partners, the background characteristics and general sexual practices that might predispose them to condom breakage, so that programme planners can know who to target with informational material.

Not having witnessed a condom demonstration and inconsistency of condom use were key determinants of reporting breakage in this study, as has been reported elsewhere $[12,13]$. The women in this study who reported a breakage were more likely to be alcohol users, also reported in other studies $[14,15]$. There have not been, to our knowledge, any studies of condom breakage that compare women who have vaginal and anal sex, although a study of heterosexual and gay men in Australia [16] found that gay men had higher rates of breakage. In this study, we found that women who practised anal sex were twice as likely to report breakages as those women who did not practice anal sex. Sex workers in Karnataka are being taught how to apply a condom on a man's penis, yet those who reported this also reported more breakage, also found in another study in the United States [17]. Not observed in other studies, but likely correlated with inexperience, was the fact that young women under 20 years were over three times more likely to have reported a condom breakage than older women. In addition, these young women are likely to be found in brothels, where there was almost a 5-fold risk of breakage, than among women who entertained their clients in public places. This is an unexpected result, as we had believed that breakage was more likely to occur in less structured situations, such as having sex standing up, furtively or hurriedly, or in the dark [18]. Neither of these factors (age and brothel work) has been associated with breakage in other studies, but this is possibly because we had a large randomly sampled group in our study, whereas other studies may have focused on more homogeneous groups of respondents. These findings are therefore important for programme planning in the Indian context. Other factors, found to be important in other sex worker studies in Thailand and China $[14,19]$, such as a history of violence were important in the univariate analysis but not significant when controlling for other factors in the regression analysis.

Accessing young girls in lodges, and especially brothels, is particularly difficult in India, as many are trafficked and under the legal age for sex [20,21]. However, there is clearly a need to continue to try to reach them, and once reached, to conduct condom demonstrations and talk about alcohol use, anal sex, and how to reduce condom breakage and disease transmission. Finally, more research is needed in this population around the details of practices in specific sexual encounters. As with many aspects of HIV transmission probability, we find that the youngest women, those who engage in risky activities such as inconsistent condom use, alcohol use and anal sex and those least exposed to HIV programmes, that have condom demonstrations as part of the programme, are also the most vulnerable to condom breakage. An important direction for research in this population now is a comprehensive study that can evaluate the relative contributions of personal versus circumstantial factors such as condom fit, lubricant use, multiple condom use, lack of experience, furtive sex, and rough sex act that have been found to be important in other studies $[9,14,22-28]$. For now, the sex worker programmes need to make a special effort to seek out women who appear to be more susceptible to breakage than others, and provide information and skills to help them reduce their risk for HIV infection.

\section{Acknowledgements}

This research was funded by the Bill \& Melinda Gates Foundation. The views expressed herein are those of the authors, and do not necessarily reflect the official policy or position of the Bill \& Melinda Gates Foundation. This article has been published as part of BMC Public Health Volume 11 Supplement 6, 2011: Learning from large scale prevention efforts - findings from Avahan. The full contents of the supplement are available online at URL.

\section{Author details}

${ }^{1}$ CHARME-India Project, Bangalore; India KHPT office, IT Park $5^{\text {th }}$ floor, \#1-4 Rajajinagar Industrial Area, Behind KSSIDC Admin Office, Rajajinagar,

Bangalore 560 044, India. ${ }^{2}$ Centre hospitalier affilié universitaire de Québec, Canada; Unité de recherche en santé des populations, Centre de recherche du CHA de Québec, Hôpital du Saint-Sacrement, 1050 chemin Ste-Foy, Québec G1S 4L8, Canada. ${ }^{3}$ Karnataka Health Promotion Trust, Bangalore, India; IT Park $5^{\text {th }}$ floor, \#1-4 Rajajinagar Industrial Area, Behind KSSIDC Admin Office, Rajajinagar, Bangalore 560 044, India. ${ }^{4}$ Centre for Global Public Health, Faculty of Medicine, University of Manitoba, 771 Mc Dermot Avenue, Medical Rehabilitation Building, Room R070, Winnipeg, Manitoba R3E 0T6, Canada.

\section{Authors' contributions}

$\mathrm{JB}$ conceived of the study, supervised the analysis and wrote the manuscript; SR conducted the data analysis and commented on the manuscript; MA, SI, SM and BMR provided support for data analysis; and SI, RW and BMR designed the original studies from which the data were extracted. MA, RW and SM provided constructive feedback on the manuscript.

\section{Competing interests}

The authors declare that they have no competing interests.

Published: 29 December 2011

\section{References}

1. Holmes KK, Levine R, Weaver M: Effectiveness of condoms in preventing sexually transmitted infections. B World Health Organ 2004, 82:454-461.

2. Ahmed S, Lutalo T, Wawer M, Serwadda D, Sewankambo NK, Nalugoda F: HIV incidence and sexually transmitted disease prevalence associated with condom use: a population study in Rakai, Uganda. AIDS 2001, 15(16):2171-9.

3. Crosby R, DiClemente RJ, Holtgrave DR, Wingood GM: Design, measurement, and analytical considerations for testing hypotheses 
relative to condom effectiveness against non-viral STIs. Sex Transm Infect 2002, 78:228-231.

4. Paz-Bailey G, Koumans EH, Sternberg M, Pierce A, Papp J, Unger ER, Sawyer M, Black CM, Markowitz LE: The effect of correct and consistent condom use on chlamydial and gonococcal infection among urban adolescents. Arch Pediatr Adolesc Med 2005, 159(6):536-542.

5. De Visser RO, Smith AMA: When always isn't enough: implications of the late application of condoms for the validity and reliability of selfreported condom use. AIDS Care 2000, 12(2):221-224.

6. Grimley DM, Annang L, Houser S, Chen H: Prevalence of condom use errors among STD clinic patients. Am J Health Behav 2005, 29(4):324-330.

7. Macaluso M, Blackwell R, Jamieson DJ, Kulczycki A, Chen MP, Akers R, Kim D, Duerr A: Efficacy of the male latex condom and of the female polyurethane condom as barriers to semen during intercourse: a randomized clinical trial. Amer J Epidemiol 2007, 166(1):88-96.

8. Steiner M, Piedranita C, Joanis C, Glover L, Spruyt A: Condom breakage and slippage rates among study participants in eight countries. Int Fam Plan Perspec 1994, 20:220-226.

9. Mukenge-Tshibaka L, Alary M, Geraldo N, Lowndes C: Incorrect condom use and frequent breakage among female sex workers and their clients. Int J STD AIDS 2005, 16:345-347.

10. Indian Council of Medical Research (ICMR), Family Health International (FHI): National interim summary report, Integrated Behavioural and Biological Assessment (IBBA), Round 1 (2005-7). New Delhi, India; 2007.

11. Ramesh BM, Beattie TS, Isac S, Washington R, Jagannathan L, Reza-Paul S, Blanchard J, Moses S: Changes in risk behaviours and prevalence of sexually transmitted infections following HIV preventive intervention among female sex workers in five districts in Karnataka state, south India. Sex Transm Infect 2010, 86:17-i24.

12. Albert AE, Warner DL, Hatcher RA, Trussell J, Bennett C: Condom use among female commercial sex workers in Nevada's legal brothels. Am J Public Health 1995, 85(11):1514-1520.

13. Warner L, Newman DR, Kamb MC, Fishbein M, Douglas JM, Zenilman J, Anna CD, Bolan G, Rogers J, Peterman T: Problems with condom use among patients attending sexually transmitted diseases clinics: Prevalence, predictors and relation to incident gonorrhea and Chlamydia. Am J Epidemiol 2008, 167(3):341-349.

14. Choi YPS, Chen KL, Jiang ZQ: Client perpetuated violence and condom failure among female sex workers in south western China. Sex Transm Dis 2008, 35(2):141-144.

15. Fisher JC, Cook PA, Kapiga SH: Alcohol use before sex and HIV risk: situational characteristics of protected and unprotected encounters among high-risk African women. Sex Transm Dis 2010, 37(9):571-578,

16. Richters J, Gerofi J, Donovan B: Why do condoms break or slip off in use? An exploratory study. Int J STD AIDS 1995, 6(1):11-8.

17. Sanders SA, Graham CA, Yarber WL, Crosby RA: Condom use errors and problems among young women who put condoms on their male partners. JAMWA 2003, 58(2):95-8.

18. Crosby RA, Graham CA, Yarber WI, Sanders SA: Problems with condoms may be reduced for men taking ample time to apply them. Sexual Health 2010, 7(1):66-70

19. Rugpao S, Tovanabutra S, Beyrer C, Nuntakuang D, Yutabootr Y, Vongchak T, Dedoer MA, Celentano DD, Nelson KE: Multiple condom use in commercial sex in Lamphum province, Thailand: a community generated STD/HIV prevention strategy. Sex Transm Dis 1997, 24(9):546-549.

20. Joffres C, Mills E, Joffres M, Khanna T, Walia H, Grund D: Sexual slavery without borders: trafficking for commercial sexual exploitation in India. Int J Equity Health 2008, 7(22), doi:10.1186/1475-9276-7-22.

21. Silverman JG, Decker MR, Gupta J, Maheshwari A: HIV prevalence and predictors among rescued sex-trafficked women and girls in Mumbai, India. J Acq Immun Def Synd 2006, 43(5):588-593.

22. Reece M, Herbenick D, Sanders SA, Monahan P, Temkit M, Yarber WL: Breakage slippage and acceptability outcomes of a condom fitted to penile dimensions. Sex Transm Infect 2010, 84:143-149.

23. Smith AM, Jolley D, Hocking J, Benton K, Gerofi J: Does penis size influence condom slippage and breakage? Int J STD AIDS 1998, 9:444-447.

24. Crosby R, Yarber WL, Graham CA, Sanders SA: Does it fit okay? Problems with condom use as a function of self-reported poor fit. Sex Transm Infect 2010, 86:36-38.
25. European Working Group on HIV Infection in Female Prostitutes: HIV infection in European female sex workers: epidemiological link with use of petroleum-based lubricants. AIDS 1993, 7(3):401-8.

26. Rugpao S, Tovanabutra S, Beyrer C, Nuntakuang D, Yutabootr Y, Vongchak T, Dedoer MA, Celentano DD, Nelson KE: Multiple condom use in commercial sex in Lamphum province, Thailand: A community generated STD/HIV prevention strategy. Sex Transm Dis 1997, 24(9):546-549.

27. Wu J, Goo E, Li N: Condom use and breakage among women in Shanghai. Journal of Reproduction and Contraception 2010, 21(1):41-52.

28. Voeller B, Coulson AH, Bernstein GS, Nakamura RM: Mineral oil lubricants cause rapid deterioration of latex condoms. Contraception 1989, 39:95-102.

doi:10.1186/1471-2458-11-S6-S14

Cite this article as: Bradley et al.: Determinants of condom breakage among female sex workers in Karnataka, India. BMC Public Health 2011 11(Suppl 6):S14.

\section{Submit your next manuscript to BioMed Central and take full advantage of:}

- Convenient online submission

- Thorough peer review

- No space constraints or color figure charges

- Immediate publication on acceptance

- Inclusion in PubMed, CAS, Scopus and Google Scholar

- Research which is freely available for redistribution

Submit your manuscript at www.biomedcentral.com/submit
C Biomed Central 